\title{
Prospects of biodrainage to mitigate problems of waterlogging and soil salinity in context of India - A review
}

\section{P. Masilamani}

Discipline of Seed Science and Technology, Anbil Dharmalingam Agricultural College and Research Institute, Tamil Nadu Agricultural University, Tiruchirappalli-620027 (Tamil Nadu), India

\section{K. Arulmozhiselvan*}

Discipline of Soil Science and Agricultural Chemistry, Anbil Dharmalingam Agricultural College and Research Institute, Tamil Nadu Agricultural University, Tiruchirappalli620027 (Tamil Nadu), India

\section{A. Alagesan}

Discipline of Agronomy, Anbil Dharmalingam Agricultural College and Research Institute, Tamil Nadu Agricultural University, Tiruchirappalli-620027 (Tamil Nadu), India

*Corresponding author. E. mail: selvarulindia@gmail.com

\begin{abstract}
Major parts of agricultural lands in arid and semi-arid regions of India are affected by soil salinity and waterlogging in canal command area and outside. Waterlogging is caused by a rising water table and poor drainage conditions. Stress due to waterlogging and salinity are serious to plants in all stages from seed germination to active growth and maturity. Unmanaged affected agricultural lands turn into low productive marshlands in the long run. Physical provision of surface or sub-surface drainage structures can rescue in such a situation. Yet, high skill and investment are required in the installation and maintenance of such structures. Alternatively, biodrainage method has been evolved as an effective method recently world over. In biodrainage, plants are raised over a larger area, which can transpire and remove an enormous amount of water from the soil. Plants having adequate adaptive traits and tolerance mechanisms are desirable to mitigate waterlogging and salinity. Biodrainage is suitable in rainfed and irrigated conditions. Planting of right plant species in optimum population and geometry decides the efficiency of biodrainage. Further, combining biodrainage with the conventional drainage can improve land and water productivity. Eucalyptus is the most suitable tree species for biodrainage as it has well performed in versatile environments. It possesses appreciable tolerance to salinity, sodicity and waterlogged conditions of the soil. Fast-growing with a straight trunk, deep rooting ability, low shading effect and high transpiration capacity are promising characteristics of this tree. Prominent woody species like Acacia nilotica, Dalbergia sissoo, Hardwickia binata can also be grown for high profit.
\end{abstract}

Keywords: Biodrainage, Drainage, Eucalyptus, Salinity, Waterlogging

\section{Article Info}

https://doi.org/10.31018/

jans.vi. 2285

Received: May 7, 2020

Revised: May 29, 2020

Accepted: June 9, 2020

\section{How to Cite}

Masilamani, P. et al. (2020). Prospects of biodrainage to mitigate problems of waterlogging and soil salinity in context of India - A review . Journal of Applied and Natural Science, 12(2): 229 - 243 https://doi.org/10.31018/ jans.vi.2285

\section{INTRODUCTION}

Waterlogging and salinity are widespread constraints in major areas of irrigated agriculture and rainfed lands where the groundwater table is fluctuating at shallow depth. The waterlogged area in India is about 4.5 million (M) ha, comprising $2.2 \mathrm{M}$ ha in canal commands and $2.3 \mathrm{M}$ ha outside of canal commands. Similarly, the salt-affected area is around $6.73 \mathrm{M}$ ha, comprising $2.96 \mathrm{M}$ ha as saline soil and $3.77 \mathrm{M}$ ha as sodic soil. The waterlogged and salt-affected lands may be found separately or exist together. In Tamil Nadu saltaffected lands comprise of 13231 ha as saline soil and 354784 ha as sodic soil totalling to 368015 ha (Gupta and Goyal, 2017)
The waterlogged condition may be present over a long period, covering the whole or a part of a year. The depth of occurrence of the water table may change with seasons. The water table is the level below which the soil is fully saturated. Water table occurring closer to ground surface moisturizes the upper strata of soil by capillary fringes. Waterlogging results not only due to the rising of the water table, but also due to very poor drainage conditions of surface soil strata. Constant standing water or saturation cuts off the direct supply of atmospheric air to soil pores, making plants roots deprived of oxygen supply. The flow of oxygen through pore filled water occurs by diffusion, which is a very slow process. Greater is 
the saturation, and smaller is the rate of diffusion (Neira et al., 2015). This situation poses several problems in agricultural production.

Waterlogging creates anaerobic conditions in the soil which may kill the beneficial aerobic bacteria, boosts the greenhouse effect by promoting the growth of methanogens which produce methane, consistently maintains low soil temperature, builds up high salt concentration on soil surface, and substantially lowers crop yields. Less aerated waterlogged condition combined with salinity inhibit seed germination and growth of plants, encourage the growth of water-loving weeds which compete with crops for nutrients, and on a long run, a large part of agricultural land is transformed into marshes (Parkash and Mohan, 2016).

Proper measures are required to tackle the increasing problems of waterlogging and salinity development. Traditional surface and subsurface drainage methods for draining the water are costly and may cause eco-degradation and leaching of nutrients. Surface drainage removes excess water from the surface into low lying furrows through slants. Sub-surface method of drainage requires proper layering of tiles or buried drainage pipes in the underground, which demands high technical skills.

There are many other ways of managing waterlogging problems. Biodrainage is one of the costeffective agroforestry models, in which trees are grown along with crops either at bunds or by intercropping. By the process of transpiration, trees continuously remove a substantial amount of water from surface soil strata, thereby lowering the water table. Trees also benefit on the long term by giving forest products. This concept of biodrainage has recently emerged as most effective and highly economical measure practicable everywhere (Heuperman, 1992; Gafni, 1997; Kapoor, 2001; Mahmood et al., 2001; Heuperman et al., 2002; Dagar, 2014; Kamra et al., 2019). Biodrainage may be defined as "Draining out of excess soil water in the atmosphere through deeprooted plants using their bio-energy" (Ram et al., 2008; Dubey, 2012; Chauhan et al., 2012).

In biodrainage approach, trees having certain adaptive and functional characteristics are selected and grown in waterlogged lands. Trees with larger leaves, deeper roots and fast-growing habits are generally chosen. Further, these trees must not release any allelopathic substance in the soil to inhibit the growth of nearby crops. The aim of biodrainage is to siphon out a large amount of water from soil and let out to atmosphere. One top example is Eucalyptus, which has a very high rate of transpiration rate of each tree about 1250 litres per day. Other species include Populus, Casuarina, etc. In the process of biodrainage, about 98 per cent of absorbed water is expected to be transported by xylem upwards for transpira- tion, and only 2.0 per cent is retained by the plant for maintaining the turgidity. Biodrainage can be a control measure for waterlogged lands with water table within three meters beneath (Parkash and Mohan, 2016). In this review paper, information regarding the characteristics of waterlogged soils, soil salinity development, concepts of conventional methods and biodrainage approaches, adaptive responses of plants, desirable traits of tree species for their water discharging capability and practical benefits of biodrainage are briefly presented.

Characteristics of waterlogged soils: In normal soils, oxygen replenishment is aided by aeration capacity of the soils. Atmospheric air freely exchanges with soil air replenishing oxygen in a continuous process. Conversely, waterlogging causes a saturated condition resulting in low oxygen concentration (hypoxia) in soils. As most soil pores are plugged with water, it cuts off direct airexchange. Consequently, the atmospheric oxygen diffuses in the soil through the water in a very small amount as the solubility of oxygen is low $\left(0.28 \mathrm{~mol} \mathrm{~m}^{-3}\right.$ at $\left.20^{\circ} \mathrm{C}\right)$. In partially saturated soil, the diffusivity of oxygen in water-filled pores is about 10000 fold slower than through air-filled soil pores. Thus, hypoxia rapidly occurs in waterlogged soils as the dissolved oxygen is rapidly utilized by bacteria and roots (Ahmed et al., 2013). When saline soils become waterlogged crops increase the concentrations of $\mathrm{Na}^{+}$and $\mathrm{Cl}^{-}$in plant shoots in response to salinity which subsequently reduces the shoot growth and manifests itself as an adverse effect on growth and survival of plants. Growing of tolerant crops identified by breeding methods is necessary to cope up in this situation. If the condition is a long term flooding, a complete absence of oxygen (anoxia) causes another kind of water stress, which leads to change in microflora by favouring the growth of anaerobic microorganisms of the soil. Anaerobic microorganisms use electron acceptors such as ions of sulphate, nitrate, or sulphur as alternatives to oxygen and ultimately produce ethylene and other metabolic products in large amounts, which are deleterious to crops. Tree species tested in different experimental conditions accumulated a large amount of $\mathrm{Na}^{+}$and $\mathrm{Cl}^{-}$ions in shoot tissues (Table 1) under waterlogged conditions when compared to a welldrained situation (Barrett, 2003).

Waterlogged conditions not only result due to excess water supply in the command areas but also due to landform pattern, surface topography, subsurface barrier, the fine texture of soils, poor soil drainage, inappropriate irrigation practice, unsuitable cropping pattern, insufficient natural drainage and proximity to the river flood plain. Upward capillary fringe from increasing groundwater table gradually blocks all the pore spaces in the soil, finally fully slowly saturates the soil profile. The 
Table 1. Concentrations of $\mathrm{Na}^{+}$and $\mathrm{Cl}^{-}$in shoot tissues of woody perennials.

\begin{tabular}{|c|c|c|c|c|c|}
\hline \multirow[t]{2}{*}{ Plant Species } & \multirow[t]{2}{*}{ Tissue } & \multicolumn{2}{|c|}{$\begin{array}{l}\text { Concentrations of } \mathrm{Na}^{+} \text {in } \\
\text { tissues (mmol g }{ }^{-1} \text { dry } \\
\text { weight) }\end{array}$} & \multicolumn{2}{|c|}{$\begin{array}{l}\text { Concentrations of } \mathrm{Cl}^{-} \text {in } \\
\text { tissues ( } \mathrm{mmol} \mathrm{g}^{-1} \text { dry } \\
\text { weight) }\end{array}$} \\
\hline & & $\begin{array}{c}\text { Drained } \\
\text { (aerated) }\end{array}$ & $\begin{array}{c}\text { Waterlogged } \\
\text { (hypoxic) }\end{array}$ & $\begin{array}{c}\text { Drained } \\
\text { (aerated) }\end{array}$ & $\begin{array}{c}\text { Waterlogged } \\
\text { (hypoxic) }\end{array}$ \\
\hline Acacia ampliceps & Phyllodes & 0.29 & 0.78 & - & - \\
\hline Atriplex amnicola & Leaves & 5.00 & 5.59 & 4.12 & 8.53 \\
\hline Casuarina glauca & Top half shoot & 0.15 & 0.59 & 0.27 & 0.72 \\
\hline Eucalyptus camaldulensis & Top half shoot & 0.21 & 1.98 & 0.24 & 1.66 \\
\hline Eucalyptus globulus & Leaves & 0.30 & 0.69 & 0.67 & 1.20 \\
\hline Vitis vinifera & $\begin{array}{l}\text { Leaves top third } \\
\text { shoot }\end{array}$ & 0.69 & 1.38 & 1.19 & 0.68 \\
\hline
\end{tabular}

(Source: Barrett, 2003)

free water standing above the ground surface appears as waterbody. The appearance of saturated soil is darker than the surrounding soil. The dominance of the growth of algae and hydrophytic plants can be noticed (Raouf et al., 2012). Following waterlogging soil salinization normally occurs especially in arid and semi-arid regions.

The growth and development of plants under waterlogging are mainly hindered by reduced levels of oxygen in the soil around the root zone (Christianson et al., 2010). Resorting to deep tillage and proper measures of drainage may improve aeration in submerged soils. Sub-soil manuring can also be practised by placing a large volume of $\mathrm{N}$-rich organic matter within and above the impervious clay layers (Celestina et al., 2018). Providing adequate land drainage is necessary to improve crop productivity in the waterlogged area for reducing soil submergence, salinity control and relieving new area for agriculture purposes. Globally the total arable land has increased from 1371 $M$ ha in 1961 to 1533 Mha in 2009 which may not be expanded further due to anticipated account of the continuing urbanization (Ausubel et al., 2013). Ministry of Water Resources, Government of India has specified limits of depth of water table (DWT) from the ground surface in order to categorize saturated soils as waterlogged/ critical soils $(<2$ $\mathrm{m})$, potentially waterlogged soils $(2-3 \mathrm{~m})$ and safe area $(>3 \mathrm{~m})$ for the purpose of taking up land improvement measures from 1991 onwards. Usually, the height of capillary fringe in soils varies from 0.9 to $1.5 \mathrm{~m}$, corresponding to coarse to finetextured soils.

Impact of waterlogging on soil salinity: Dominantly climate and topography are major controlling factors of salinization (Schofield and Kirby, 2003; Nosetto et al., 2008; Xu et al., 2019). With increasing aridity, the problems of salinity increase manifold. Topography also influences salinity by the redistribution of water and adjusting water table below or above ground.

Shallow water depth accomplice side by side with accumulation of salts in soil profile activated by high evaporative demands in dryland areas (Singh, 2013). On the other hand, when the groundwater level moves toward the surface in the rainy season, the soil salinity is reduced (Michael, 2009). However, after the rain recurrence of evaporation leads to accumulation of salts on the surface (Bennett et al., 2009). The magnitude of accumulation of salts in the soil profile is related to the type of vegetation on the land, amount of annual rainfall, rise and fall behaviour of groundwater, the pattern of climate and land topography.

In a 10-year period study, the hydrological and salinity impacts of 11 selected Eucalyptus species/ ecotypes planted in a biodrainage system in two extreme waterlogging/ salinity conditions in a valley of Israel were different. In irrigation supported waterlogged slightly saline site $(650 \mathrm{~mm}$ annual rainfall) the water uptake by the trees was insufficient to control the rising water table, whereas in more saline/ alkaline drier rainfed location (450 $\mathrm{mm}$ annual rainfall) from the fourth year after planting groundwater dropped below $3 \mathrm{~m}$ from the soil surface (Gafni and Zohar, 2007; Singh, 2017). In another study conducted in central Argentina, water table depth was impacted by topography, whereas land use pattern exerted a stronger influence on the state of salt accumulation. In a soil layer of $0-2 \mathrm{~m}$, with an increase in water table depth, there was a decrease in the amount of accumulated salts and reached zero beyond $5 \mathrm{~m}$ depth (Fig. 1). Distinctly accumulation of the high amount of salts was found in tree plantations when the water table was at a shallow depth which was nearly four-fold more in concentration than cropland or grassland (Nosetto et al., 2013). Salinity build-up in dryland areas may occur due to changes in water balance in the catchment area, by remobilization of salts stored underground. Sudden indication of salinity on surface soil is the indicator of the rise in the water table that would have started a decade back. In terms of electrical conductivity $(E C)$ of soil saturation extract $\left(E C_{e}\right)$ soil salinity is generally classified for crops raised in medium and fine-textured soils (Table 2). In 


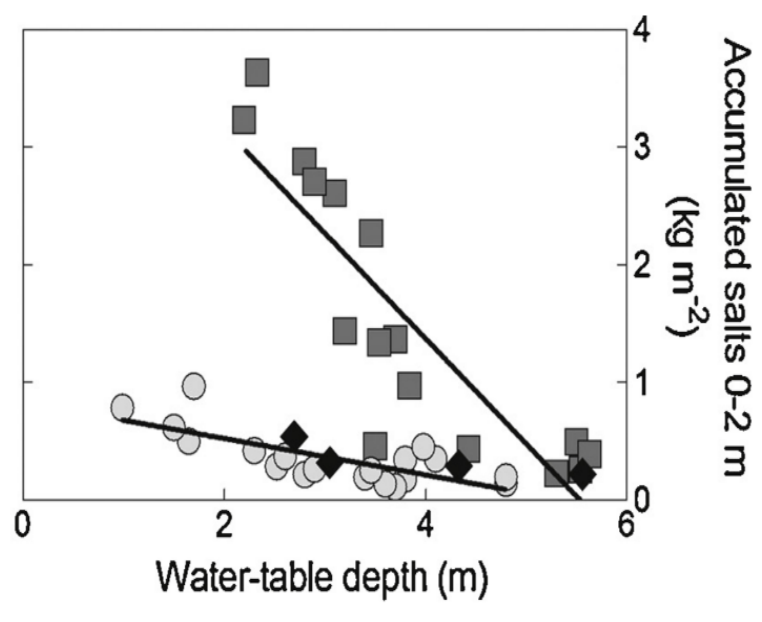

tree plantation cropland

grassland

Fig. 1. Impact of depth of water table on accumulation of salt in the soil profile (Source: Nosetto et al., 2013).

sandy and loamy sand textured soils, the same salinity effect can be realized at the half value of each $\mathrm{EC}_{\mathrm{e}}$ limit (Richards, 1954; Ritzema, 1994). Waterlogged soils can be saline, saline-sodic, and sodic soils. Saline soils contain high concentrations of soluble salts in the combinations of chlorides and sulphates of calcium, magnesium and sodium which form as white encrustations on the soil surface particularly in drylands (Stirzaker et al., 2002)

Sodic soils have soil $\mathrm{pH}>8.5$ that can extend in severity up to $\mathrm{pH} 11.0$, high exchangeable sodium percentage (ESP >15), varying EC $\left(E C e<4 \mathrm{dS} \mathrm{m}^{-}\right.$ ${ }^{1}$ ) and low soil organic matter $\left(<5 \mathrm{~g} \mathrm{~kg}^{-1}\right)$. In these situations, due to pedogenic processes, precipitation of calcium may usually occur as a thick $\mathrm{CaCO}_{3}$ layer (kankar pan) below the illuvial layer of soil profile. The saline-sodic soils have high levels of soluble salts as well as sodium ions.

Poor quality irrigation water is an important limiting factor of crop productivity. In waterlogged soils particularly there is a dire need to control the accumulation of salts in soil solution as well as deposition on the soil surface. Otherwise, undesirable quality of water may unfavourably result in high soil salinity and sodicity, reduced cation exchange, impaired nutrient availability, increased dispersion of clays, destruction of soil structure, reduced aeration, and restrictive infiltration. Commonly irrigation water measuring EC lower than $0.7 \mathrm{dS} \mathrm{m}^{-1}$ causes no hazard to most crops while EC higher than $3.0 \mathrm{dS} \mathrm{m}^{-1}$ may restrict the growth of most crops. The brackish water measuring EC beyond 0.7 up to $3.0 \mathrm{dS} \mathrm{m}^{-1}$ can be safely irrigated in the canal for salt-tolerant crops and may cause foliage injury in sprinkler irrigation. Brackish water can also be used for trees under agroforestry. Particularly Eucalyptus, Acacia, Casuarina,
Poplar, Mesquite and Tamarisk tolerate well (Lauchli and Epstein, 1990). Furthermore, it is imperative to adopt appropriate drainage methods to remove surplus water gained through a rise in the water table or excessive irrigation for the control of soil salinity.

Need for proper method of drainage: On agricultural lands problems of waterlogging and subsequent build-up of salinity slowly develop possibly due to the presence of fine-textured soil or impervious sub-surface soil layer, which results in low soil permeability. Particularly flat lands with soils that have developed over the restrictive geological layer and receive excessive rainfall become waterlogged. Compaction of subsoil may also result in lands under continuous cultivation, where tillage machineries are often used on wet soil.

In India, 2.0 $\mathrm{M}$ ha area is severely waterlogged saline soils in arid/semi-arid states of Haryana, Punjab, Rajasthan and Gujarat and 1.0 $\mathrm{M}$ ha each in the coastal and black cotton vertisol regions. In 2025 , it is expected that about 13.0 M ha area in irrigation commands will be affected by waterlogging and soil salinity. Unless remedial practices followed, increased use of saline/alkali groundwater in several northwestern and southern states might accelerate the hazard to over 20.0 million ha by 2050 (Anonymous, 2015).

No drainage system is needed in the irrigated lands in semi-arid areas if the groundwater table is deep $(>3.0 \mathrm{~m})$. With shallow water table, salt accumulation on surface soil by rising water table occurs if the ratio of potential evapotranspiration to total applied water (irrigation and precipitation) is less than 0.6 (Bastiaanssen et al., 2001). Drainage systems in arid and semi-arid regions are primarily aimed to remove the accumulated salts from the root zone, lower the groundwater levels and control the development of secondary salinization. These purposes can be achieved by both pipe and open drains. In humid regions establishment of drainage systems is primarily aimed to reduce the water content around the root zone and improve adequate aeration soon after excessive rainfall or irrigation. Secondarily, drainage systems help to improve access and trafficability for timely planting and harvesting operations. Open drainage systems are the most common for such conditions (Gupta, 2016).

Selection of appropriate drainage systems is needed to control the depth of water table and soil salinity, wherever possible. Establishing the correct engineering methods of field drains will benefit on the long term. Field drains for surface drainage, and subsurface drainage are different. Apart from internal horizontal flow of seepage water along the slope, surface runoff also reaches the field drains by flow-through row furrows or by sheet flow. Field drains are simply designed as V-shaped, with side slopes within 6 to 1 (Ritzema et al., 1996; Long et al., 
Table 2. Soil salinity effect on crop stand in medium and fine-textured soils.

\begin{tabular}{lll}
\hline $\mathbf{E C}_{\mathbf{e}}\left(\mathbf{d} \mathbf{S ~ m}^{-1}\right)$ & Classification & Crop stand \\
\hline $0-2$ & Non-saline & Not affected \\
$2-4$ & Slightly saline & Sensitive crops affected \\
$4-8$ & Saline & Many crops affected \\
$8-16$ & Strongly saline & Only tolerant crops possible \\
$>16$ & Extremely saline & A few very tolerant crops possible \\
\hline
\end{tabular}

Source: Ritzema (1994)

Table 3. Design parameters of subsurface drainage for different climatic regions.

\begin{tabular}{lllllll}
\hline \multicolumn{2}{l}{ Drainage coefficient $\left(\mathbf{m m ~ d}^{-1}\right)$} & & \multicolumn{2}{l}{ Drainage depth $\left(\mathbf{D}_{\mathrm{d}}\right)$} & \multicolumn{2}{l}{ Drain spacing $\left(\mathbf{D}_{\mathbf{s}}\right)$} \\
\hline Climate & Range & Optimal & Outlet & $\mathbf{D}_{\mathrm{d}}(\mathbf{m})$ & Soil texture & $\mathbf{D}_{\mathbf{s}}(\mathbf{m})$ \\
\hline Arid & $1-2$ & 1 & Gravity & $0.9-1.2$ & Light & $100-150$ \\
Semi-arid & $1-3$ & 2 & Pumped & $1.2-1.8$ & Medium & $50-100$ \\
Sub humid & $2-5$ & 3 & & & Heavy & $30-50$ \\
\hline
\end{tabular}

(Source: Ritzema et al., 2008; Kamra, 2013)

2017).

In order to restrain the water table at the desired level, subsurface drainage is preferred. Tubewell drainage and mole drainage are applied only in very specific conditions. Mole drainage rapidly removes excess surface water. Tubewell drainage can be provided for quickly controlling the water table and salinity in agricultural areas. It consists of pumping from a series of wells an amount of groundwater equal to the drainage requirement. The success of tubewell drainage depends on many factors, including hydrological conditions of the area, physical properties of the aquifer to be pumped and those of the overlying fine-textured layers (Kamra et al. 2019).

Substantial improvement in crop yields in subsurface drainage has been recorded in projects implemented in different states of India. Subsurface drainage increased cropping intensity by $40-50 \%$, farm income by $200-300 \%$, and yields of rice
$(>50 \%)$, wheat and cotton $(>100 \%)$ crops. Further, based on the practical outcome of IndoDutch drainage projects, the design parameters (Table 3) viz., drainage coefficient, drain spacing and depth of subsurface drainage were standardized (Ritzema et al., 2008; Kamra, 2013).

Concept of biodrainage: Recent developments in drainage systems employ underground installations of drain pipes for gravity flow or vertical pipes/ wells for pumped drain water disposal. These systems are relatively costly while installation and after that in maintenance (Kamra et al., 2019).

Under these circumstances, the concept of biodrainage has been evolved as a cost-effective natural means of draining water to sustain irrigated agriculture world over. It is getting momentum at present due to its several advantages. Biodrainage is a method of raising plants over a larger area, which can transpire an enormous

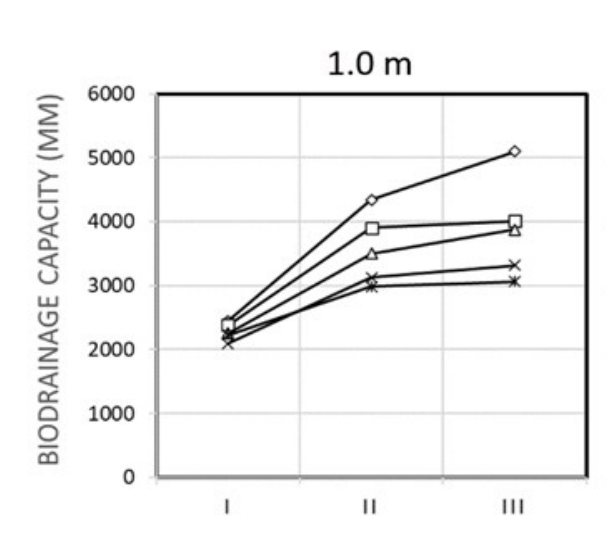

Water table depth
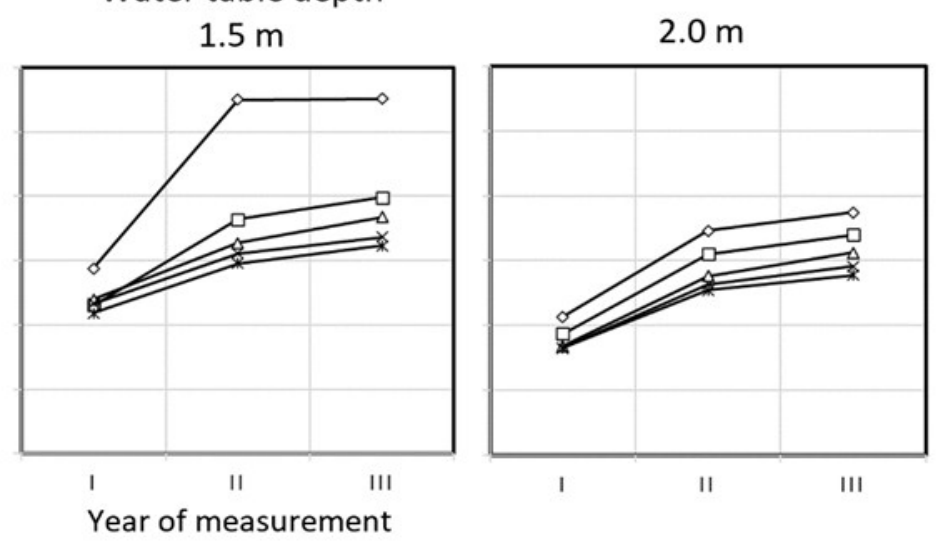

Groundwater salinity $\left(\right.$ EC dS m $\left.{ }^{-1}\right) \rightarrow \quad \sim 0.4 \quad \rightarrow-3.0 \quad \rightarrow-6.0 \quad * 9.0 \quad * 12.0$

Fig. 2. Biodrainage capacity of Eucalyptus for different water table depth (Source: Chhabra and Thakur, 1998). 
Biodrainage Plantation Area (10\%)

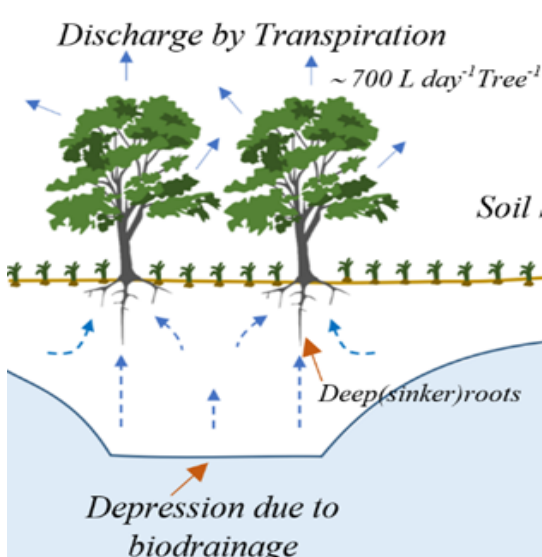

Cropping Area (90\%)

Recharge by Rain/Irrigation

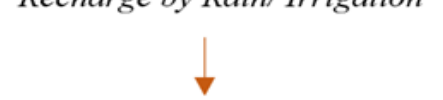

Soil Surface

Transpiration from crop $4 \sim 7 \mathrm{~L} \mathrm{day}^{-1} \mathrm{~m}$ Shallow roots $>$

Groundwater Table $>$
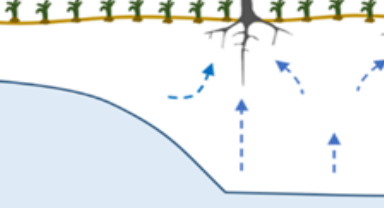

Impervious layer

Fig. 3. Mechanisms of recharge, discharge and fall of the water table in biodrainage showing depression effect of biodrainage by tree having sinker root system for absorption of water from deeper layers of soil strata and canopy for transpiration at $\sim 700 \mathrm{~L} \mathrm{day}{ }^{-1}$. Shallow rooted field crops are not capable of the depressing groundwater table.

amount of water and tolerate waterlogging and salinity.

Commonly tree plantations are established as biodraining plants for long-range benefits, instead of shrubs or annuals. By the transpiration of a large amount of absorbed water tree plantations also remove substantial salts and minerals and utilize them in biomass production (Venkatraman and Ashwath, 2016). Water balance refers to the amount of water removed from lands that are equal to the amount of water recharged. Thus, on a daily basis biodrainage plantations can attempt to maintain the water balance majorly and salt balance to some extent.

In a lysimeter study, the measured biodrainage capacity ( $\mathrm{mm}$ year ${ }^{-1}$ ) of Eucalyptus decreased with an increase in groundwater depth. Relatively biodrainage capacity increased at groundwater depth of $1.5 \mathrm{~m}$ rather than at 1.0 and $2.0 \mathrm{~m}$ depth in the second year, which may be due to a better root proliferation with non-saline water (Fig. 2). When years advanced, biodrainage capacity increased progressively, possibly due to expected growth of root and shoot biomass. In addition, it was noticed that biodrainage capacity was highest when the groundwater salinity was lowest and vice versa. This effect was more pronounced in the second and third years. This might be due to the impact of salinity which might have interfered in the extraction of water by the roots by its osmotic effect (Chhabra and Thakur, 1998).

Compared to physical drainage systems which are normally established after he development of waterlogging and salinity problems, biodrainage is a preventive technique which aims to avoid such problems in canal commands. This technique is

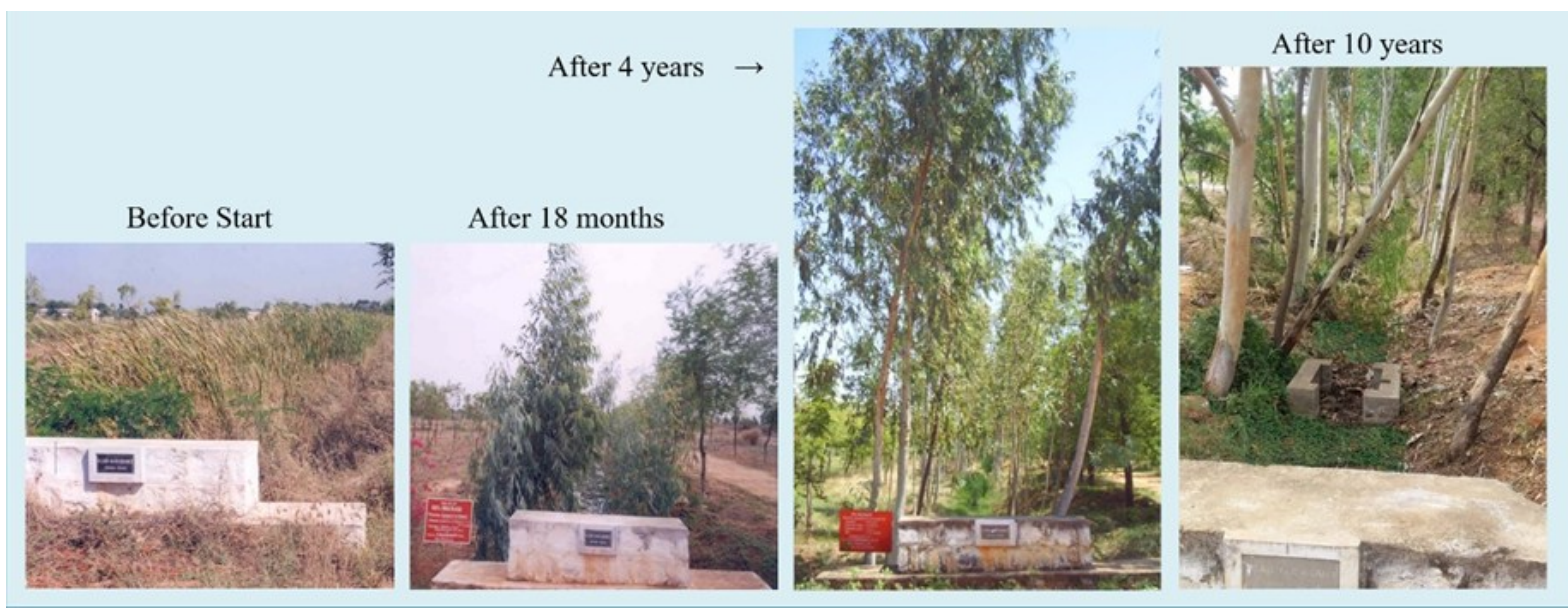

Fig. 4. Effect of Eucalyptus strip along irrigation cum drainage canal over the years (Source: Masilamani et al., 2003). 
very useful when the soil salinization has not still begun to a serious level due to the rise in the groundwater level (Kamra et al., 2019). Biodrainage proved as an effective option to intercept seepage by trees planted along a canal and watercourses. Species such as Acacia nilotica, Dalbergia sissoo, Sesbania grandiflora and Casurina equisetifolia intercepted $86 \%, 84 \%, 72 \%$ and $72 \%$ of canal seepage respectively, in saline vertisols regions of India (Patil et al., 2005).

Biodrainage systems may be established under both rainfed and irrigated conditions. Selection of right plant species and planting with an optimum population in a suitable plant geometry would help to achieve the desired soil moisture regime (Sarkar et al., 2018; Singh and Lal, 2018). Combining biodrainage system with conventional drainage and farming possibly would improve land and water productivity as well as safeguard the environment (Chowdhury et al., 2011).

Under rainfed conditions when plantations are established, advantageously the soil bulk density is reduced by the presence of abundant roots which may enhance groundwater recharge as well as facilitate roots to draw water from the subsurface flow. In irrigated areas, selection of tree species with high transpiration rates are necessary to alleviate waterlogging caused by canal seepage. Hence, for biodrainage growing usual crops as practiced in conventional drainage should not be allowed as it may end up with poor performance with high incurred cost (Singh and Lal, 2018). Identifying the right tolerant plant species or introducing tolerance mechanisms in plants will be the most successful economical approach in implementing biodrainage methods.

Tree roots usually grow to anchor the trunk and proliferate in search of water and nutrients horizontally or even vertically downwards. In moist fertile soil, roots remain confined to 1-2 m depth and extend a few metres around the trunk horizontally. Dry situations may induce root growth to penetrate vertically down even up to $20 \mathrm{~m}$. Hence, this kind of rooting is known as the dimorphic root system, comprising surface root system which includes subterranean roots around the trunk and sinker root system, which includes solitarily roots growing vertically down. Sinker roots are mainly involved in biodrainage by vertically transporting the groundwater to trunk for evapotranspiration (Fig. 3). They are also capable of distributing water in upward and downward directions by moving water from the wet zone to dry zone in the soil profile (Devi et al., 2016).

By morphology, most surfaces of roots are insulated by bark for longer lengths, which is a lignin material. Lignified portions of roots are not involved in water, metabolites and ions absorption. In surface and sinker roots system, a small portion of roots present at the end has the function of $a b-$ sorption. This non-lignified primary root portion having root hairs can only establish contact with soil particles and function with mycorrhizal associations, nutrient uptake, and water absorption (Brunner et al., 2015).

The extent of the presence of each type of root system varies with plant species. Poplus deltoides has majorly surface root system confined within $80 \mathrm{~cm}$ soil layer extending upto $120 \mathrm{~cm}$ radius. While tree species, viz., Prosopis cineraria, Acacia nilotica, Eucalyptus tereticornis has both root systems and sinker roots reach down up to 250 $\mathrm{cm}$. In drier regions, Prosopis pallida can extend roots until the water table is reached at $20-25 \mathrm{~m}$ depth (Hultine et al., 2003; Devi et al., 2016). Deep-rooted trees are effective in biodrainage process.

Bringing agricultural lands under canal irrigation is a key cause of raising the water table. After the introduction of Bhakra canal irrigation in western Haryana, the water table which was stabilized at about $28 \mathrm{~m}$ depth has attained a shallow depth at $6 \mathrm{~m}$ from surface within few decades, and currently 50 per cent of lands have become saline besides the waterlogging problems. Although these problems are common in most of the irrigated agriculture systems, adoption of biodrainage can be a remedy in all locations, and at least 10 per cent of the area can be allotted for biodrainage process (Heuperman et al., 2002).

Eucalyptus sp., which has robust sinker roots and greater transpiring ability ( $>1200 \mathrm{~L}$ day ${ }^{1}$ ) is preferably planted in biodrainage plantations. They are also capable of redistributing water both upward and downward within soil profile in response to dry and wet conditions in a better way than many other trees and plants. By sap flow measurements using heat ratio this phenomenon has been noticed commendably with $E$. camaldulensis and E. platypus (Burgess et al., 1998; Stephen et al., 2001; Andrew and Peter, 2018).

Recharge by interception, throughfall and stemflow in biodrainage plantation: During rainfall, biodrainage plantations must harvest most of the rainwater; hence soil profile can be enriched with fresh water. Compared to other tree species interception loss of rainwater is less in Eucalyptus. Water loss due to evaporation is also minimum in E. camaldulensis. In a study, it was found out that out of $1105 \mathrm{~mm}$ rainfall received $E$. globulus trees collected $1.5 \%$ water by stemflow, $21.9 \%$ water by interception while the remaining $76.6 \%$ water was received as throughfall (Samraj, 1984; Livesley et al., 2014).

When soil becomes saturated, biodrainage process begins with water uptake from the saturated soil by the roots, transportation of water to shoots and end with transpiration of water by the plant foliage. Selection of plants for biodrainage needs to be efficient in every process of absorption, 
transportation and transpiration of water. Transpiration capacity of plants is the main measure of plant efficiency. It is the direct indication of the amount of withdrawal of groundwater (Fig. 3). However, the transpiration process depends on climatic conditions, plant species, the density of plantation, the area under plantation, water supply and root system (Chen et al., 2012).

Crop factor, which is the ratio of transpiration to pan evaporation, can be another useful parameter to assess the capability of biodrainage plantation (Gupta, 2005). This ratio varies with plant type, soil texture, clay content, depth of water table, groundwater salinity, leaf area index, etc. Particularly increase in groundwater salinity reduces water uptake by trees and other plants (Ren et al., 2019). After designing the biodrainage system, water balance in the land must be monitored on

Table 4. Prospective traits of trees in alleviating waterlogging and salinity.

\section{Eucalyptus - as most suitable tree species for biodrainage}

Luxurious water consumption

The trunk grows straight hence low shading effect

Fast rooting rate: Rooting rate in 6 months $-1.2 \mathrm{~m} ; 16$ months $-2.85 \mathrm{~m} ; 30$

months $-4.15 \mathrm{~m}$ in Doon Valley in Uttaranchal;

6 -year trees of 12 species rooted up to $2.1 \mathrm{~m}$ in California;

20-year trees rooted up to $10 \mathrm{~m}$ in northern Victoria (Australia)

Fast-growing tree in tropics/ subtropics having favourable wood properties and $\mathrm{C}$ sequestering ability

Water table depression effect : Eucalyptus hybrid (5.34\%) $>$ Eucalyptus tereticornis C-10 (4.95\%) > Eucalyptus tereticornis C-130 (4.63\%) > Eucalyptus tereticornis C-3 (2.79\%)

Salinity tolerance : E. occidentalis > E. camaldulensis

\section{Rooting characteristics Eucalyptus sp.}

E. grandis - Roots of 9-year-old trees reached up to $28 \mathrm{~m}$ in South Africa.

E. Camaldulensis - Tap roots reached $1.6 \mathrm{~m}$ in 5 years, $2.9 \mathrm{~m}$ in 15-years in high rainfall zone at Jabalpur; up to $10 \mathrm{~m}$ in Rajasthan

E. tereticornis - Roots of 16-year trees reached up to $3.75 \mathrm{~m} ; 20$-year trees reached up to $4.40 \mathrm{~m}$

E. globulus - Roots of 20-year trees confined to upper $3 \mathrm{~m}$ in Nilgiris Hills

E. occidentalis - Sinker roots reached up to $2 \mathrm{~m}$ in the desert area of Israel

\begin{tabular}{|c|c|}
\hline \multicolumn{2}{|l|}{ Ability of carbon sequestration } \\
\hline $\begin{array}{l}\text { E. globulus sequestered } 5-6 \mathrm{Mg} \mathrm{C} \mathrm{ha}^{-1} \text { in north-west India in } 5 \text { years, while } 3.0- \\
11.5 \mathrm{Mg} \mathrm{C} \mathrm{ha}^{-1} \text { in south-west Australia in } 10 \text { years }\end{array}$ & Lal (2009) \\
\hline $\begin{array}{l}\text { E. tereticornis sequestered } 1.63 \mathrm{Mg} \mathrm{C} \mathrm{ha}^{-1} \text { in Haryana in } 15 \text { years; E. camaldu- } \\
\text { lensis sequestered } 6.55 \mathrm{Mg} \mathrm{C} \mathrm{ha}^{-1} \text { in coastal Bangladesh in } 20 \text { years; while Aca- } \\
\text { cia nilotica sequestered } 26.18 \mathrm{Mg} \mathrm{C} \mathrm{ha}^{-1} \text { in Punjab province in Pakistan in } 10 \\
\text { years }\end{array}$ & Wicke et al. (2013) \\
\hline \multicolumn{2}{|l|}{ Water discharging ability of trees } \\
\hline E. Camaldulensis - 3-year-old trees transpired $1360 \mathrm{~mm} \mathrm{ha}^{-1}$ & Zohar et al. (2008) \\
\hline Acacia nilotica - 5-year-old trees transpired $2225 \mathrm{~mm} \mathrm{ha}^{-1}$ & $\mathrm{NIH}(1999)$ \\
\hline $\begin{array}{l}\text { Elaeagnus angustifolia L., Populus spp., Ulmus pumila L. have greater discharg- } \\
\text { ing ability }\end{array}$ & Khamzina et al. (2006) \\
\hline $\begin{array}{l}\text { Discharging rate: Eucalyptus }>\text { Prosopis juliflora }>\text { Callistemon lanceolatus }>\text { Melia } \\
\text { azedarach }>\text { Terminalia arjuna }>\text { Pongamia pinnata }\end{array}$ & Dagar (2014) \\
\hline \multicolumn{2}{|l|}{ High Biomass Production } \\
\hline $\begin{array}{l}\text { Prosopis juliflora> Acacia nilotica> Casuarina equisetifolia> } \\
\text { Terminalia arjuna> Pithecellobium dulce>Eucalyptus tereticornis (20-year plan- } \\
\text { tation produced above-ground biomass of } 30-60 \mathrm{t} \mathrm{ha}^{-1} \text { in alkali soil) }\end{array}$ & Singh et al.(2008) \\
\hline \multicolumn{2}{|l|}{ Soil organic C enrichment } \\
\hline $\begin{array}{l}\text { Acacia spp> Eucalyptus spp (due larger litterfall from Acacia and fast decompo- } \\
\text { sition rate) }\end{array}$ & Gill and Abrol (1993) \\
\hline
\end{tabular}

Dong et al. (1992)

Calder et al. (1997)

Ram et al. (2007)

Trabado and Wilstermann (2009)

Tokyet al. (2011)

Zohar et al. (2008)

Ram et al. (2007)

Dye (1996)

Ram et al. (2007) 

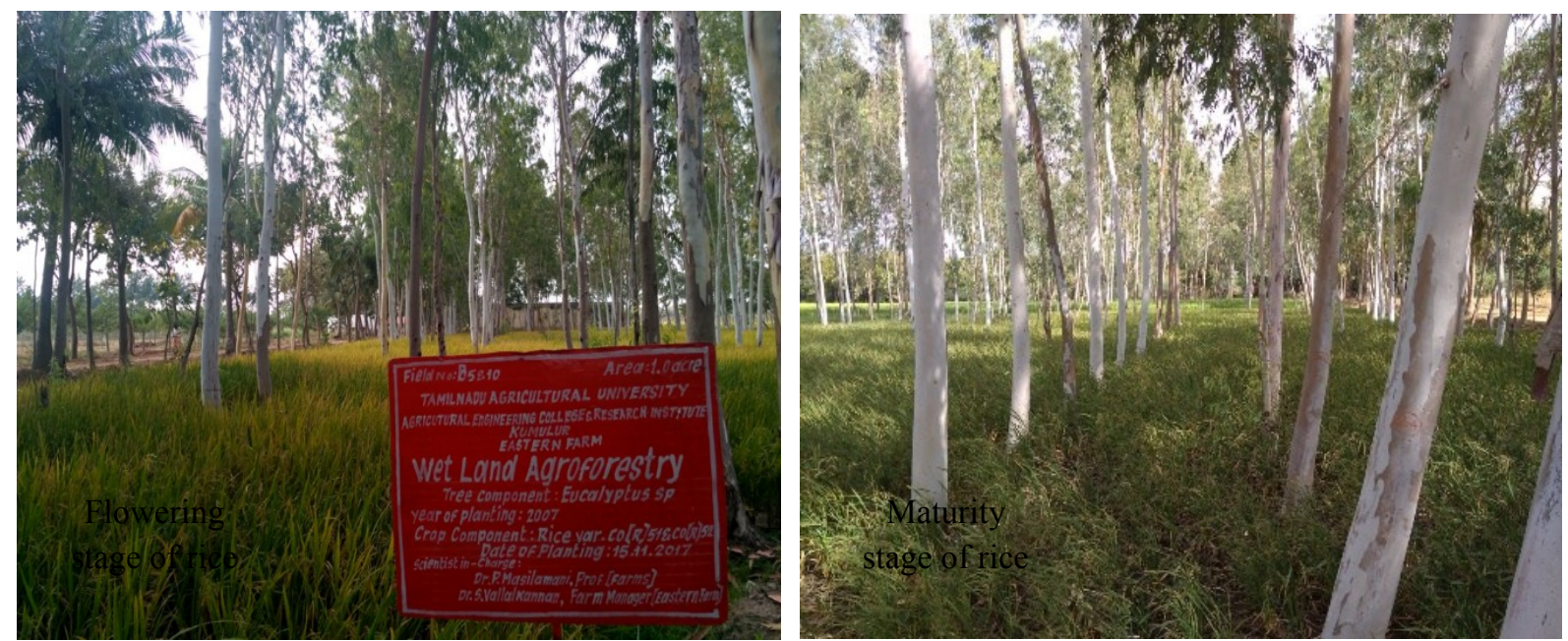

Fig. 5. Eucalyptus + Rice intercropping in wetland farm of Kumulur, Tamil Nadu (Source: Masilamani et al., 2019) .

shortterm and longterm basis.

Infiltration capacity of the soil is another component of biodrainage which must be monitored carefully. Low infiltration affects recharge of rainwater in the soil profile and during excessive rain may cause runoff loss of freshwater and soil erosion. Water use in biodrainage system is another component to be monitored. Apart from soil limitations, physiological functions of the plant play a major role in water use. Myers et al. (1998) indicated that water use is related to stomatal response to high vapour pressure deficit, rather than soil salinity. As evaporative demand increases, crop factor would drastically decrease.

In small plants and trees, water transport is governed by turgor pressure of cells maintained at various levels. Turgor pressure varies within the plant system at different positions according to internal moisture content, physiological activity, solute concentration, etc. In order to attain the water balance in various parts of plant water transport occurs multi-directionally within the plant system. Water is the one that can be adjusted readily and quickly within the plant tissue. For the purpose of exhibiting cell stiffness living nonwoody plants maintain $70-95 \%$ water, whereas woody plants retain about $50 \%$ water in their tissues (Hirons and Thomas, 2018). During transpiration, upward transmission of water happens as a primary event against the acceleration due to gravity.

Water movement occurs by the driving force linked with the status of water pressure in soil, plant, and atmospheric air as a continuum. The pressure difference (potential) is the driving force which moves water from the place of higher pressure to a place of lower pressure. By virtue of location, water potential develops within plants, which is the resultant potential accounted by the summation of osmotic, pressure and gravitational potentials. As the resultant potential is against gravity, it is lower than atmospheric pressure, and hence it is referred to as negative pressure or suction.

Water potential in the soil is subjected to matric suction of soil particles which increases with drying. In waterlogged soils matric suction is meagre. The salinity of waterlogged soils exhibits the greater osmotic potential of water in soil solution and makes it harder for plants to absorb water. The ability of water absorption by plants is eventually limited by the soil water potential at the permanent wilting point (PWP). For many agricultural crops, PWP is fixed at $-1.5 \mathrm{MPa}$ (-15 bars), however temperate trees can absorb water even up to the range of -2 to $-4 \mathrm{MPa}$ (Hirons and Thomas, 2018). Further, soil texture also affects the water uptake by plants particularly under dryland situations, as the volume of water available for uptake is about one-third to half in coarse-textured soil when compared to medium and fine-textured soils (Nielsen and Vigil, 2018).

Overall, water transport in plants is carried out by the potential water gradients established in different locations and stages in the soil-plant-aircontinuum. Sequentially water moves from lower suction to higher suction regions in a tree starting from soil (-0.3 MPa) through root xylem (-0.6 $\mathrm{MPa})$, trunk xylem (-0.8 MPa), Leaf cell walls $(-1.0$ $\mathrm{MPa})$, leaf air space (-7.0 MPa) to the outside air (-10 to $-100 \mathrm{MPa})$ of the atmosphere. Water potential of air changes widely due to changes with relative humidity and air temperature (Andrew and Peter, 2018). Trees lose more than $95 \%$ of the water in atmospheric air by transpiration. Besides the cooling effect of heated leaves, incidentally, transpiration process allows carbon dioxide and oxygen to diffuse in and out and delivers minerals that are dissolved in the moving water to the growing points of the tree (McElrone et al., 2013).

Adaptive mechanisms of plants for waterlogging and salinity: Waterlogging and soil salinity 
Table 5. Relative tolerance of prominent trees in waterlogged condition.

\begin{tabular}{|c|c|c|c|}
\hline Category & Tolerant & Moderately tolerant & Slightly tolerant \\
\hline \multirow[t]{2}{*}{ Soil alkalinity } & $(\mathrm{pH}>10)$ & $(\mathrm{pH} 9-10)$ & $(\mathrm{pH} 8.0-9.0)$ \\
\hline & $\begin{array}{l}\text { Prosopis juliflora, Acacia } \\
\text { nilotica, } \\
\text { Casuarina equisetifolia }\end{array}$ & $\begin{array}{l}\text { Eucalyptus tereticornis, Cap- } \\
\text { paris decidua, Tamarix artic- } \\
\text { ulate, Pithecellobium dulce, } \\
\text { Prosopis alba, P. cineraria, } \\
\text { Cassia siamea } \\
\qquad\left(\text { ECe } 10-15 \mathrm{dS} \mathrm{m}^{-1}\right)\end{array}$ & $\begin{array}{l}\text { Grevillea robusta, Aza- } \\
\text { dirachta indica, Melia azeda- } \\
\text { rach, Leucaena leucocepha- } \\
\text { la, Hardwickia binata, Popu- } \\
\text { lus deltoides, Tectona gran- } \\
\text { dis } \\
\left.\qquad \text { (ECe } 7-10 \mathrm{dS} \mathrm{m}^{-1}\right)\end{array}$ \\
\hline Soil salinity & $\begin{array}{l}\text { Prosopis chilensis, } \\
\text { Tamarix troupii, } \\
\text { Acacia tortillis, } \\
\text { Acacia nilotica, } \\
\text { Casuarina equisetifolia, } \\
\text { Callistemon lanceolatus, } \\
\text { Eucalyptus camaldulensis }\end{array}$ & $\begin{array}{l}\text { Acacia auriculaeformis, Eu- } \\
\text { calyptus umbellate, } \\
\text { Terminalia arjuna, } \\
\text { Pongamia pinnata, } \\
\text { Dalbergia sissoo, } \\
\text { Acacia catechu, } \\
\text { Acacia Senegal, } \\
\text { Prosopis cineraria }\end{array}$ & $\begin{array}{l}\text { Casuarina cunninghamiana, } \\
\text { Eucalyptus tereticornis, Aca- } \\
\text { cia auriculiformis, Guazuma } \\
\text { ulmifolia, leucaena shanno- } \\
\text { ni, Samaneasaman, Albizzia } \\
\text { caribea }\end{array}$ \\
\hline $\begin{array}{l}\text { Coastal re- } \\
\text { gions }\end{array}$ & $\begin{array}{l}\text { Casuarina equisetifolia, } \\
\text { Terminalia catappa, } \\
\text { Lannea coromandelica, } \\
\text { Tamarix sp. }\end{array}$ & $\begin{array}{l}\text { Cocos nucifera, } \\
\text { Glochidion sp. } \\
\text { Calophyllum inophyllum, } \\
\text { Barringtonia asiatica }\end{array}$ & $\begin{array}{l}\text { Palmae, } \\
\text { Metroxylon sagu, Nypa fruti- } \\
\text { cans, } \\
\text { Pandanus sp. }\end{array}$ \\
\hline $\begin{array}{l}\text { Coastal water- } \\
\text { logged regions }\end{array}$ & $\begin{array}{l}\text { Avicennia, Aegiceras, Ceri- } \\
\text { ops, Rhizophora, Bruguiera, } \\
\text { Sonneratia, Heriteria }\end{array}$ & $\begin{array}{l}\text { Excoecaria, Scyphiphora, } \\
\text { Nypa, and Xylocarpus }\end{array}$ & $\begin{array}{l}\text { Eucalyptus spp. Casuarina } \\
\text { equisetifolia, Anacardium } \\
\text { occidentale, Acacia auricu- } \\
\text { laeformis, Azadirachta indica }\end{array}$ \\
\hline
\end{tabular}

(Source: Gill et al., 1990; Singh and Singh 1993; Dagar, 2014)

cause abiotic stresses in plants. Anoxic conditions under waterlogging end up in the production of phytotoxic compounds in soil, while saline conditions affect the uptake of water and nutrients by plants. Plants capable of adaption make morphological, anatomical, biochemical, and metabolic changes suitably according to stress and stressfree situations (Parent et al., 2008). From hypoxic to development of anoxic condition induce synthesis of about 20 selective anaerobic stress proteins to promote the activity of energy generation in the absence of oxygen, which are mainly the enzymes of glycolysis, ethanolic fermentation, carbohydrate metabolism and also others involved in aerenchyma formation and cell pH control (Vartapetian, 2006). Morphological and anatomical adaptations primarily include the formation of lenticels, aerenchyma and adventitious roots. Greater number of hypertrophied lenticels formation under the submerged condition in Quercus sp. may be indicative of the adaptive response of tolerance to flooding (Parelle et al., 2006).

Aerenchyma development is an important adaptive response in flood-tolerant plants, particularly in bottomland woody species. These lacunae gas spaces increase porosity in shoot and may ventilate phytotoxic volatile compounds produced in the root to the atmosphere through the shoot
(Pezeshki, 1996). The proportion of aerenchyma in plants of wetlands and non-wetlands can be used as a factor for determining the level of adaptation (Vasellati et al., 2001).

Flooding the lands induce the production of adventitious roots near the soil surface which may take up the adaptive function in place of decaying basal roots that fail to transport water and nutrients (Mergemann and Santer, 2000). Plants in response to waterlogging showed a decline in cytosolic $\mathrm{pH}$ initially to stimulate the shift of biochemical function of alcohol dehydrogenase by inhibiting lactate dehydrogenase. Reduction in cytosolic $\mathrm{pH}$ occurs due to the production of lactic acid during fermentation, soon after waterlogging (Chang et al., 2000). Physiologically plants respond to soil submergence immediately by reducing stomatal conductance. Plants also exhibit remarkable perturbation in chlorophyll fluorescence parameters. In Cork oak (Quercus variabilis) and China wingnut (Pterocarya stenoptera) an obvious reduction in the maximum quantum efficiency of photosystem II was recorded (Hua et al., 2006). Similarly, waterlogging induced stress causes plants to produce elevated concentrations of reactive oxygen species (ROS) like superoxide $\left(\mathrm{O}_{2}^{-}\right)$, hydrogen peroxide, and hydroxyl $\left(\mathrm{OH}^{-}\right)$, which damagingly react with cellular molecules and me- 
tabolites, and impair the metabolic reactions of PS II (Ashraf, 2009; Ashraf, 2012). In the adverse situation of excessive ROS production, every plant has an adaptive mechanism of production of antioxidants to neutralize the effect of ROS. Under the waterlogged condition, one of such kinds of enzymatic antioxidant defence reaction was observed in maize seedling (Tang et al., 2010).

Unlike waterlogging stress, plants employ different mechanisms to overcome stress due to soil salinity. Halophytes have already evolved features to thrive normally in saline conditions, while glycophytes lethally suffer when confronting salinity stress. As a counteraction to salinity stress, otherwise known as hyperosmotic stress, plants undergo different physiological changes which causes membrane interruption, nutrient imbalance, and impaired ability to detoxify ROS (Gupta and Huang, 2014). As one of the salinity adaptive tolerance mechanisms plants accumulate a greater amount of soluble sugars in plant parts. In the leaves of Bruguiera parviflora decreased amount of starch and increased amount of reducing and non-reducing sugars was recorded while the salinity level of the soil was elevated (Parida et al., 2004). In response to salt stress upregulation of 10 genes associated with osmoregulation was observed in halophyte plant species Spartina alterniflora (Baisakh et al., 2006).

Exploring genetic di $\square$ erences in the plant varieties for tolerance to waterlogging, salinity, sodicity would take a long way to go because experimentation with long-duration plant species in varying waterlogged situations requires studies for a long period. Discovery of genes and linked markers to various tolerance mechanisms will empower breeders to pyramid tolerance genes and make successful progress in future (Benny et al., 2019).

Tolerance of trees to waterlogging, soil salinity and sodicity: Salt affected soils develop in this world by natural processes and anthropogenic activities. Soil rehabilitation by establishing agroforestry systems with suitable planting techniques and salt-tolerant plant species are effective ways to improve productivity and desalinize saltaffected lands (Vargas et al., 2018).

In saline/sodic waterlogged soils for taking up biodrainage measure Eucalyptus based agroforestry system was found effective in semi-arid regions of Haryana (Ram et al., 2008). Apart from that very salt-tolerant species like Casuarina obesa and Acacia stenophylla can be grown well in strongly saline areas. In intermittently irrigated dryland saline soils tree species like Casuarina cunninghamiana, Eucalyptus argophloia, E. camaldulensis, E. melliodora, E. moluccana, E. sideroxylon, and $E$. tereticornis can be grown with the use saline irrigation water of EC 4-8 dS $\mathrm{m}^{-1}$. More salttolerant species like E. occidentalis and Casuarina glauca and E. camaldulensis can grow satisfacto- rily with extremely saline (16-20 dS $\mathrm{m}^{-1}$ ) irrigation water (Marcar and Crawford 2004). Information gathered from many reports (Table 4) showed that among many tree species evaluated Eucalyptus sp. has performed well due to its characteristic traits of growth behaviour and tolerance mechanisms.

In waterlogged saline soil, the performance of E.tereticornis grown along with wheat - rice rotation for 6 years in paired strip row planting method was evaluated. During the $6^{\text {th }}$ year tree population planted at $1 \mathrm{~m} \times 1 \mathrm{~m}$ spacing (300 trees ha $\left.{ }^{-1}\right)$ performed well and yielded $33.5 \mathrm{t} \mathrm{ha}^{-1}$ timber dry wood, sequestered $15.2 \mathrm{Mg} \mathrm{C} \mathrm{ha}^{-1}$, transpired at a rate of $68.0 \mathrm{~L}$ day $^{-1}$ and discharged $745 \mathrm{~mm}_{\text {year }}{ }^{-1}$ water from soil, ultimately lowering water table upto $43 \mathrm{~cm}$ (Dagar et al., 2016).

Mitigation of problems of waterlogging and salinity: In India, total waterlogged command area occupies $1.72 \mathrm{M}$ hectares, which is $1.93 \%$ of the major and medium irrigation command (88.9 $\mathrm{M}$ ha) areas (RRSSC, 2009). Approximately $7.0 \mathrm{M}$ ha is affected by salinity and alkalinity due to waterlogging. Out of which about 54,000 ha is in the Cauvery delta zone of Tamil Nadu.

A pilot study conducted at Agricultural Engineering College and Research Institute, Kumulur, Tiruchirappalli District, Tamil Nadu indicated that among plants planted along irrigation cum sewage discharge canal Eucalyptus tereticornis recorded higher survival percentage $(94 \%)$ when compared to banana $(65 \%)$ at the stage of 18 months (Fig. 4). Due to introduction of biodrainage measure water stagnation, foul smell, mosquito problem and harmful weed growth were not observed along the canal, and the nearby field area has also become dry for the period beyond 10 years (Masilamani et al., 2003). In another study conducted in the same location, Eucalyptus + Rice intercropping was raised. The yield of rice varieties $\mathrm{CO} 51$ and $\mathrm{CO} 52$ in Eucalyptus interplanting system was $2100 \mathrm{~kg} \mathrm{ha}^{-1}$ and $2600 \mathrm{~kg} \mathrm{ha}^{-}$ 1 and in rice monoculture system was $4625 \mathrm{~kg} \mathrm{ha}$ 1 and $5000 \mathrm{~kg} \mathrm{ha}^{-1}$ respectively (Fig. 5). On costeffectiveness rice + wood biomass (Eucalyptus) system was found better than rice monoculture; hence Eucalyptus + rice would be a profitable biodrainage practice in wetland areas (Masilamani et al., 2019).

Acacia nilotica, Capparis decidua, C. sepiaria, Salvadora oleoides, S. persica and Clerodendrum phlomidis are prominent woody species which can grow on very high $\mathrm{pH}$ soils while Acacia leucophloea, A. eburnea, Mimosa hamata, Prosopis cineraria, Buteamono sperma, Diospyros tomentosa, Balanites roxburghii and Maytenus emarginata can tolerate in slightly low $\mathrm{pH}$ soils. Prosopis juliflora was found to tolerate in Typic Natrutalfs, even though the top $44 \mathrm{~cm}$ of soil had $\mathrm{pH} 10.3$, ESP of 70 , and ECe of $12 \mathrm{dS} \mathrm{m}^{-1}$. Other 
planted species failed to grow in this soil (Khamzina et al., 2006). Based on relative tolerance to waterlogging associated with salinity and sodicity of soil and irrigation water tree crops can be generally grouped (Table 5 ) for observing satisfactory growth in the prevailing situation (Gill et al., 1990; Singh and Singh, 1993; Dagar, 2014). For establishing biodrainage plantation planned effort is required for initial land preparation and taking up planting. Then practically little effort is required in the maintenance of plantations from third year onwards. Thereafter, economic worth of trees increases with the age of trees (Ram et al., 2008; CSD Manual, 2018). Commonly biodrainage plantations are taken up in strip or block planting methods.

Strip planting along channels: Usually trees are planted in strips along with main irrigation channels to intercept seepage. The size of the strip may be planned according to the land area available (Pancel, 2015).

Strip planting inland area: Tree strips are established within cropland. Based on economic considerations and competition for water and nutrient, the distance between two biodrainage strips is to be decided. Accordingly, the area allotment for tree strips and cropland is set. At least one-tenth of the area may be allotted within the land, in one or more strips of trees to have a realizable benefit of biodrainage. In high saline soils, trees planting can be done in a raised bed or parallel ridge. Planting two rows of trees in a strip at every $8.5 \mathrm{~m}$ apart or adjusting tree planting in ten strips per hectare would be a convenient plan (Ram et al., 2011; Pancel, 2015).

Block plantation: Blocks of trees can be planted at a required distance between the croplands. In this method excess water in the cropped area is drawn by the fall of the water table under the tree plantation (Pancel, 2015).

\section{Conclusion}

In biodrainage process, plants transpire plenty of water and reduce the depth of water table thereby prevent rising of salts to the soil surface. Usually, trees are planted due to their deep rooting capacity, tolerance mechanisms and continuous action of transpiration as direct effect trees do not remove a large amount of salts by absorption. Most trees thrive well to grow even in high saline/ sodic and waterlogged conditions. Eucalyptus is the most suitable tree species for biodrainage as it has well performed in versatile environments. It possesses appreciable tolerance to salinity, sodicity and waterlogged conditions of soil. Fastgrowing with a straight trunk, deep rooting ability, low shading effect and high transpiration capacity are some of positive characteristics associated with this tree. Acacia nilotica, Dalbergia sissoo, Hardwickia binata are prominent woody species which can also be grown. Biodrainage plantations can be established in paired row strips giving equal spacing between strips. At the most, ten strips can be planned in a hectare of cropped land allotting at least ten per cent of total area. It is a cost-effective method; trees absorb $\mathrm{CO}_{2}$ from the air and reduce greenhouse effect; trees act as wind barriers; tree debris enriches organic matter levels of soil; weed growth is reduced by shade effect. Further, transpiration and shade effect of plantation cool the atmosphere and soil surface. Measurable $C$ is sequestered until harvest. Profitable income can be realized by plant products having food and fodder values and after the harvest by plant products having fuelwood and small timber.

\section{REFERENCES}

1. Ahmed, F.M., Rafii, M.Y., Ismail, M.R., Juraimi, A.S., Rahim, H.A., Asfaliza, R. and Latif, M.A. (2013). Waterlogging Tolerance of Crops: Breeding, Mechanism of Tolerance, Molecular Approaches, and Future Prospects. BioMed Research International, 1-10.

2. Andrew, D.H. and Peter, A.T. (2018). Tree Water Relations. Applied Tree Biology, First Edition. John Wiley \& Sons Ltd., pp 239-259.

3. Anonymous (2015). Vision 2050. Central Soil Salinity Research Institute (Indian Council of Agricultural Research), Karnal, India, pp 31.

4. Ashraf, M.A. (2009). Improving salinity tolerance of plants through conventional breeding and genetic engineering: An analytical comparison. Biotech. Adv., 27: 744-752.

5. Ashraf, M.A. (2012) Waterlogging stress in plants: A review. African Journal of Agricultural Research, 7 (13): 1976-1981.

6. Ausubel, J.H., Wernick, I.K. and Waggoner., P.E. (2013). Peak farmland and the prospect for land sparing. Popul. Dev. Rev., 38: 221-242.

7. Baisakh, N., Subudhi, P. K., and Parami, N. P. (2006). cDNA-AFLP analysis reveals differential gene expression in response to salt stress in a halophyte Spartina alterniflora Loisel. Plant Science, 170(6): 1141-1149.

8. Barrett L.E.G. (2003). The interaction between waterlogging and salinity in higher plants: causes, consequences and implications. Plant and Soil, 253: 35-54.

9. Bastiaanssen, W.G.M., Brito, R.A.L., Bos, M.G., Souza, R., Cavalcanti, E.B. and Bakker, M.M. (2001). Low cost satellite data applied to performance monitoring of the Nilo Coelho irrigation scheme, Brazil. Irrig. Drain. Syst., 15(1): 53-79.

10.Bennett, S.J., Barrett L.E.G. and Colmer, T.D. (2009). Salinity and waterlogging as constraints to salt land pasture production: a review. Agric. Ecosyst. Environ., 129: 349-360.

11.Benny, J., Pisciotta, A., Caruso, T. and Martinelli, F. (2019). Identification of key genes and its chromosome regions linked to drought responses in leaves across different crops through metaanalysis of RNA-Seq data. BMC Plant Biol. 19, 194. https://doi.org/10.1186/s12870-019-1794-y

12.Brunner, I., Herzog, C., Dawes, M.A., Arend, M. and Christoph. (2015). How tree roots respond to drought. Front. Plant Sci., 2015: 547 (1-16) https:// 
doi.org/10.3389/fpls.2015.00547

13.Burgess, S.S.O., Adams, M.A., Turner, N.C. and Ong, C.K. (1998). The redistribution of soil water by tree root systems. Oecologia. 115: 306-311.

14.Calder, I.R., Rosier, P.T.W., Prasanna, K. T. and Parameswarappa. S. (1997). Eucalyptus water use greater than rainfall input- a possible explanation from southern India. Hydrology and Earth System Sciences, 1(2): 249-256.

15.Celestina, C., Midwood, J., Sherri $\square$, S., Trengove, S., Hunt, J., Tang, C., Sale, P. and Franks, A. (2018). Crop yield responses to surface and subsoil applications of poultry litter and inorganic fertiliser in southeastern Australia. Crop Pasture Sci., 69: 303-316.

16.Chang, W.P., Huang, L., Shen, M., Webster, C., Burlingame, A.L. and Roberts, J.K. (2000). Protein synthesis and tolerance of anoxia in root tips of maize seedlings acclimated to a low oxygen environment and identification of protein by mass spectrometry. Plant physiol., 122: 295-318.

17.Chauhan, M.K., Ram, J. and Dagar, J. C. (2012). Biodrainage and carbon sequestration. Lambert Academic Publishing, Germany, (ISBN-10: 3659147095, ISBN-13: 978-3659147098) pp. 304.

18.Chen, L., Zhang, Z. and Ewers, B.E. (2012). Urban Tree Species Show the Same Hydraulic Response to Vapor Pressure Deficit across Varying Tree Size and Environmental Conditions PLOS ONE 2012, 7 (10) e47882 (1-10)

19.Chhabra, R. and Thakur, N.P. (1998). Lysimeter study on the use of bio-drainage to control waterlogging and secondary salinization in (canal) irrigated arid/semi-arid environment. Irrigation and Drainage Systems 12: 265-288. Kluwer Academic Publishers. Netherlands.

20.Chowdhury, R.S., Kumar, A., Brahmanand, P.S., Ghosh, S., Mohanty R.K., Jena, S.K, Sahoo, N. and Panda, G. C. (2011). Application of biodrainage for reclamation of waterlogged situations in deltaic Orissa. Research Bulletin No. 53. Directorate of Water Management: Bhubaneswar, India; pp 32.

21.Christianson, J.A., Llewellyn, D.J., Dennis, E.S. and Wilson, I.W. (2010). Comparisons of early transcriptome responses to low-oxygen environments in three dicotyledonous plant species. Plant Signal. Behav., 5: 1006-1009.

22.CSD Manual (2018). Tree Planting, Maintenance, and Protection Manual - 2018/06. Town of Hanna Community Services Department 302 2nd Avenue West PO Box 430 Hanna, AB Canada T0J 1 P0. Website: www.HANNA.ca

23.Dagar, J.C. (2014). Greening salty and waterlogged lands through agroforestry systems. Agroforestry Systems in India: Livelihood Security \& Environmental Services, Advances in Agroforestry, 10: 333-344. Springer Publishers, India.

24.Dagar, J.C., Lal, K., Ram, J., Kumar, M., Chaudhari, S.K., Yadav, R.K., Ahamad, S., Singh, G. and Kaur, A. (2016). Eucalyptus geometry in agroforestry on waterlogged saline soils influences plant and soil traits in North-West India. Agriculture, Ecosystems and Environment, 233: 33-42.

25.Devi, S., Angrish, R., Madaan, S., Toky, O. P. and Arya, S.S. (2016). Sinker root system in trees with emphasis on soil profile. Plant-Microbe Interaction: An Approach to Sustainable Agriculture, Springer Nature Singapore Pte Ltd. pp 463-474. DOI
10.1007/978-981-10-2854-0_21.

26.Dong, S.A., Tanji, K., Gratter, S., Karajelii, F. and Partenge, M. (1992). Irrigation and Drainage: Water quality effects on Eucalyptus - saving a threatened resource - in search of solutions, ASCE, New York, USA., pp 164-170.

27.Dubey, K. (2012). SWOT analysis for the application of biodrainage technology to phyto remediate water logged sites. Int. J. Soc. Forest., 5(2): 47-59.

28.Dye, P.J. (1996) Response of Eucalyptus grandis trees to soil water deficits. Tree Physiology, 16:(12), 233-238. https://doi.org/10.1093/treephys/16.12.233

29.Gafni, A. (1997). Irrigation and the environment: an Israeli perspective. Proceeding of the ANCID Conference, Deniliquin, NSW, Australia.

30.Gafni, A. and Zohar, Y. (2007). Hydrological and salinity impacts of a bio-drainage strategy application in the Yizre'el Valley, Israel. Hydrol. Process., 21: 2164-2173.

31.Gill, H.S. and Abrol, I.P. (1993) Afforestation and amelioration of salt-affected soils in India. Productive use of saline land. ACIAR proceedings No. 42, Canberra, pp 23-27

32.Gill, H.S., Abrol, I.P. and Gupta, R.K. (1990). Afforestation of Salt-affected soils. CSSRI, Karnal, pp 1-6.

33.Gupta, B. and Huang, B. (2014). Mechanism of salinity tolerance in plants: Physiological, Biochemical, and Molecular Characterization. International Journal of Genomics. Volume 2014: Article ID 701596, 18 pageshttp://dx.doi.org/10.1155/2014/701596

34.Gupta, S.K. (2005). A critical analysis of bio-drainage with special reference to Indian experiences. Souvenir: all India seminar reclamation of waterlogged saline soils through drainage. Institution of Engineers (Kota Chapter), Kota, pp 81-96.

35.Gupta, S.K. (2016) Integrated drainage solutions for waterlogged saline lands. Innovative Saline Agriculture, 2016: 183-200. DOI 10.1007/978-81-322-27700_9.

36.Gupta, S.K. and Goyal, M.R. (2017) Soil Salinity Management in Agriculture: Technological Advances and Applications - Innovations in Agricultural \& Biological Engineering CRC Press, 2017. ISBN 1315341778, 9781315341774.

37.Heuperman, A.F. (1992). Trees in irrigation areas: the bio-pumping concept. Trees and Natural Resources, 34: 20-25.

38. Heuperman, A.F., Kapoor, A.S. and Denecke, H.W. (2002). Biodrainage - principles, experiences, and applications. Knowledge synthesis report No. 6. International Programme for Technology and Research in Irrigation and Drainage (IPTRID), IPTRID Secretariat, Food and Agriculture Organization of the United Nations, Rome.

39. Hirons, A. and Thomas, P.A. (2018). Tree water relations. Applied Tree Biology, John Wiley \& Sons, 2018, pp 239.

40.Hua, Y.Y., Yong, F.D., Qiang, X.Z., Qing, C.F. (2006). Effects of waterlogging on the gas exchange, chlorophyll fluorescence and water potential of Quercus variabilis and Pterocarya stenoptera , Chin J. Plan. Ecolo., 30(6): 960-968.

41.Hultine, K.R., Williams, D.G., Burgess, S.O.S. and Keefer., T.O. (2003). Contrasting patterns of hydraulic redistribution in three desert phreatophytes. Oecologia. 135: 167-175. 
42.Kamra, S.K. (2013). Role of farmers' participation for effective management of groundwater recharge structures in Haryana. Proceedings of Workshop on 'Roadmap for sustainable groundwater resources in Punjab and Haryana. Organized by CGWB North West Region, Chandigarh, India, February 27, pp 8899.

43.Kamra, S.K., Satyendra Kumar, Neeraj Kumar and Dagar, J.C. (2019). Engineering and biological approaches for drainage of irrigated lands. Research Developments in Saline Agriculture. Springer Nature Singapore Pte Ltd.

44.Khamzina, A., Lamers, J.P.A., Martius,C., Worbes, M. and Vlek, P.L.G. (2006). Potential of nine multipurpose tree species to reduce saline groundwater tables in the lower Amu Darya River region of Uzbekistan. Agroforest Syst. 68: 151-165. https:// doi.org/10.1007/s10457-006-9006-9

45.Lal, R. (2009). Carbon sequestration in saline soils. J. Soil salinity water quality, 1(1-2): 30-40.

46.Lauchli, A. and Epstein, E. (1990). Plant responses to saline and sodic conditions. Agricultural salinity assessment and management. American Society of Civil Engineers. New York, pp 113-137.

47.Livesley, S.J., Baudinette, B. and Glover, D. (2014) Rainfall interception and stem flow by eucalypt street trees - The impacts of canopy density and bark type. Urban Forestry \& Urban Greening, 13(1): 192-197

48.Long, Y.W., Taib S.N.L. and Selaman, O.S. (2017) Evaluation of Critical Parameters to Improve Slope Drainage System. Hindawi Advances in Civil Engineering, 2017 : 3796423, (1-9). https:// doi.org/10.1155/2017/3796423.

49.Mahmood, K., Jim, M., Collopy, J. and P. Slavich. (2001). Groundwater uptake and sustainability of farm plantations on saline sites in Punjab province, Pakistan. Agricultural Water Management, 48: 1-20.

50.Marcar, N.E. and Crawford, D.F. (2004). Trees for saline landscapes. Rural Industries Research and Development Corporation (RIRDC), Canberra, Australian Capital Territory, pp 235.

51.Masilamani, P. and Santhana Bosu, S. and Annadurai, K. (2003). Bio drainage for degraded drainage problem lands. Leisa India, 5: 19.

52. Masilamani, P., Bhaskar, M., Vallal Kannan, S., Alex Albert and Vinothini, R. (2019). Eualyptus spp. Wetland Agroforestry: A case study of ecological benefits and site productivity. Abstract in proceedings on $28^{\text {th }}$ National Conference on Farmers Friendly Soil and Water Conservation Technologies for mitigating climate change Impact, held on 31.1.2019 to 2.2.2019 at ICAR-IISWC, Regional Centre, Udhagamandalam, pp 117.

53.McElrone, A.J., Choat, B., Gambetta, G.A. and Brodersen, C.R. (2013). Water uptake and transport in vascular plants. Nature Education Knowledge, 4(5): 6.

54.Mergemann H. and Santer, M. (2000). Ethylene induces epidermal cell death at the site of adventitious root emergence in rice. Plant Physiol., 124: 609-614.

55.Michael, A.M. (2009). Irrigation: Theory and Practice, second ed. Vikas Publishing House Pvt. Ltd, New Delhi, India.

56.Myers, B. J., Benyon, R.G., Theiveyanathan, S., Criddle, R.S., Smith, C.J. and Falkiner, R.A. (1998). Response of effluent-irrigated EucalyptusGrandis and Pinusradiata to salinity and vapour pressure deficit.
Tree Physiol., 18: 565-573.

57.Neira, J., Ortiz, M., Morales, L. and Acevedo, E. (2015). Oxygen diffusion in soils: Understanding the factors and processes needed for modeling. Chilean Journal of agricultural research, 75 (Suppl. 1): 35-44.

58.Nielsen, D.C and Vigil, M.F. (2018) Soil Water Extraction for Several Dryland Crops. Agron. J., 110:2447-2455

59.NIH (1999). National Institute of Hydrology 19992000. Biodrainage. National Institute of Hydrology. Jal Vigyan Bhawan, Roorkee, Uttaranchal.

60.Nosetto, M.D., Acosta, A.M., Jayawickreme, D.H., Ballesteros, S.I., Jackson, R.B. and Jobbagy, E.G. (2013). Land-use and topography shape soil and groundwater salinity in Central Argentina. Agricultural Water Management, 129: 120-129.

61.Nosetto, M.D., Jobbagy, E.G., Toth, T. and Jackson, R.B. (2008). Regional patterns and controls of ecosystem salinization with grassland afforestation along a rainfall gradient. Global Biochemical Cycles. https:// doi.org/10.1029/2007GB003000

62.Pancel L. (2015) Basic Outline of Tree Plantations in the Tropics. In: Pancel L., Köhl M. (eds) Tropical Forestry Handbook. Springer, Berlin, Heidelberg

63.Parelle, J., Roudaut J.P. and Ducrey, M. (2006). Light accumulation and photosynthetic response of beech (Fagus sylvatica L.) sapling under artificial shading or natural Mediterranean conditions. Annals of Forest Science, 63: 257-266.

64.Parent, C., Capelli, N., Berger, A., Crevecoeur, M. and Dat, J.F. (2008). An overview of plant responses to soil waterlogging. Plant stress, 2(1): 20-27.

65.Parida, A. K., Das, A. B. and Mohanty, P. (2004). Investigations on the antioxidative defence responses to $\mathrm{NaCl}$ stress in a mangrove, Bruguiera parviflora: differential regulations of isoforms of some antioxidative enzymes. Plant Growth Regulation, 42: (3) 213226.

66.Parkash, V. and Mohan, C. (2016). Waterlogging and salinity: Issues and challenges in restoring the land resource. International Journal of Multidisciplinary Research and Development, 3(5): 341-344.

67.Patil, B.N., Patil, S.G., Hebbara, M., Manjunatha, M.V., Gupta, R.K. and Minhas, P.S. (2005). Bioameliorative role of tree species in salt-affected Vertisols of India. J. Trop. For. Sci., 17: 346-354.

68.Pezeshki, SR. (1996). Responses of three bottomland species with different flood tolerance capabilities to various flooding regimes. Wetlands Ecology and Management 4 : 245-256.

69.Ram, J., Dagar, J.C., Khajanchi, L., Singh, G., Toky, O.P., Tanwar, V.S., Dar, S.R. and Chauhan, M.K. (2011). Biodrainage to combat waterlogging, increase farm productivity and sequester carbon in canal command areas of northwest India. Current Sci., 100(11): 1673-1680.

70.Ram, J., Dagar, J.C., Singh, G., Lal, K., Tanwar, V.K., Shoeran, S.S., Kaledhonkar, M.J., Dar, S.R. and Kumar, M. (2008). Biodrainage: ecofriendly technique for combating waterlogging and salinity. Technical Bulletin: CSSRI/ Karnal/ 9/ 2008, pp 24.

71.Ram, J., Garg, V.K., Toky, O.P., Minhas, P.S., Tomar, O.S., Dagar, J.C. and Kamra, S.K. (2007). Biodrainage potential of Eucalyptus tereticornis for reclamation of shallow water table areas in northwest India. Agroforest Syst., 69: 147-165.

72.Raouf, A.N., Al-Homaidan, A.A. and Ibraheem I. B. 
M. (2012). Agricultural importance of algae. African Journal of Biotechnology, 11(54): 11648-11658, DOI: 10.5897/AJB11.3983

73.Ren, S., White, D.A., Xiang, D., Short, T.M., Xiao, W., Chen, J., Deng, Z. and Yang, Z. (2019). Simple model of evapotranspiration by Eucalyptus plantations for data poor areas and tested using water balance data from a small catchment in Guangxi, China. Australian Forestry, 82 (Suppl.1): 66-79, DOI: 10.1080/00049158.2018.1555733

74.Richards, L.A. (1954). Diagnosis and improvement of saline and alkali soils. USDA Handbook No. 60 Washington, DC. US Government Printing Office.

75. Ritzema, H.P. (1994). Drainage principles and applications. International Institute for Land Reclamation and Improvement, P.O. Box 45. 6700 AA Wageningen, The Netherlands. pp 544.

76. Ritzema, H.P., Kselik, R.A.L. and Chanduvi, F. (1996) Drainage of Irrigated Lands: A Manual. Irrigation and water management Training manual No. 9. FAO of the United Nations, Rome.

77.Ritzema, H.P., Satyanarayana, T., Raman, S. and Boonstra, J. (2008). Subsurface drainage to combat waterlogging and salinity in irrigated lands in India: lessons learned in farmers' fields. Agric. Water Manag., 95:179-189.

78.RRSSC. (2009). Assessment of waterlogging and salt and/ or alkaline affected soils in the commands of all major and medium irrigation projects in the country using satellite remote sensing. Country Report. Government of India Regional Remote Sensing Service Centre. Indian Space Research Organisation, Jodhpur, India.

79.Samraj, P. (1984). A review of Eucalyptus globules Labill (Blue gum) Plantation in the Nilgiris. Proc. Workshop on Eucalyptus plantation, Bangalore, India, 29 June 1984. pp 19-48.

80.Sarkar, A., Banik, M., Ray, R. and Patra, S. (2018). Soil moisture and groundwater dynamics under biodrainage vegetation in a waterlogged land. Int. J. Pure Appl. Biosci., 6:1225-1233.

81.Schofield, R.V. and Kirby, M.J. (2003). Application of salinization indicators and initial development of potential global soil salinization scenario under climatic change. Global Biogeochemical Cycles, 17: 1078.

82.Singh, A. (2013). Groundwater modelling for the assessment of water management alternatives. J. Hydrol., 481: 220-229.

83.Singh, A. (2017). Waterlogging and Salinity Management for Sustainable Irrigated Agriculture. II: Engineering Measures and Biodrainage. J. Irrig. Drain Eng., 143(9): 04017036 (1-7). DOI: 10.1061/(ASCE) IR.1943-4774.0001227.

84.Singh, G. and Lal, K. (2018). Review and case studies on biodrainage: An alternative drainage system to manage waterlogging and salinity. Irrigation Drainage, 67: 51-64.

85.Singh, G., and Singh, N.T. (1993). Mesquite for the revegetation of salt lands. Technical bulletin No. 18, CSSRI, Karnal, India, pp 24.

86.Singh, Y.P., Sharma, D.K., Singh, G., Nayak, A.K.,
Mishra, V.K. and Singh, R. (2008). Alternate land use management for sodic soils. CSSRI Technical Bulletin No. 2/ 2008. CSSRI, Karnal, pp 16.

87.Stephen, S.O., Burgess, S.S.O., Adams, M.A., Turner, N.C., White, D.A. and Ong, C.K. (2001). Tree roots: conduits for deep recharge of soil water. Oecologia, 126: 158-165.

88.Stirzaker, R., Vertessy, R. and A. Sarre. (2002). Trees, water and salt - an Australian guide to using trees for healthy catchments and productive farms. Joint Venture Agroforestry Program; Rural Industries Research and Development Corporation, pp 144.

89.Tang, B., Shang-zhong, XU., Zou, XL., Zheng, YL., Qiu, FZ (2010). Changes of antioxidative enzymes and lipid peroxidation in leaves and roots of waterlogging-tolerant and waterlogging-sensitive maize genotypes at seedling stage. Agric. Sci China, 9: 651-661.

90.Toky, O.P., Angrish, R., Datta, K.S., Arora, V., Rani, C., Vasudevan, P. and Harris, P.J.C. (2011). Biodrainage for preventing waterlogging and concomitant wood yields in arid agro-ecosystems in NorthWestern India. Journal of Scientific \& Industrial Research, 70: 639-644.

91.Trabado, I.G. and Wilstermann, D. (2009). Eucalyptus Universalis. Global cultivated eucalypt forests map 2008. GIT Forestry Consulting's Eucalyptologics: Information resources on Eucalyptus cultivation worldwide.

92.Vargas, R., Pankova, E.I., Balyuk, S.A., Krasilnikov, P.V. and Khasankhanova, G.M. (2018). Handbook for saline soil management. Food and Agriculture Organization of the United Nations and Lomonosov Moscow State University.

93.Vartapetian, B.B. (2006). Plant anaerobic stress as a novel trend in ecological physiology, biochemistry, and molecular biology : 2. Further development of the problem. Russisn Journal of plant physiology, 53: 711 -738 .

94.Vasellati, V., Oesterheld, M., Medan, D., Loreti, J. (2001) Effects of Flooding and Drought on the Anatomy of Paspalumdilatatum, Annals of Botany, 88(3): 355-360, https://doi.org/10.1006/anbo.2001.1469

95.Venkatraman, K. and Ashwath, N. (2016). Transpiration in 15 Tree Species Grown on a Phytocapped Landfill Site. Hydrol. Current Res., 7(2): 1000236 (113). DOI: 10.4172/2157-7587.1000236.

96.Wicke, B., Smeets, E.M.W., Akanda, R., Stille, L., Singh, R.K., Awan, A.R., Mahmood, K. and Faaij, A.P.C. (2013). Biomass production in agroforestry and forestry systems on salt affected soils in south Asia: Exploration of GHG balance and economic performance of three case studies. J. Environ. Mgt., 127: 324-334.

97.Xu, L., Du, H. and Zhang, X. (2019) Spatial Distribution Characteristics of Soil Salinity and Moisture and Its Influence on Agricultural Irrigation in the Ili River Valley, China. Sustainability, 2019: (11) 7142 (1-17). doi:10.3390/su11247142

98.Zohar, Y., Gafni, A., Morris, J. and Shalhevet, S. (2008). Eucalyptus plantations in Israel: an assessment of economic and environmental viability. New Forests, 36: 135-157. 